\title{
Genderowy dżihad: reforma w islamie ${ }^{1}$
}

Mata liczba dziet podważajacych paradygmatyczny fundament myśli muzutmańskiej ze względu na brak $w$ nim ptci [gender] jako zasadniczej kategorii tej myśli

i jako aspektu analizy niezbędnego $w$ artykutowaniu idei muzutmańskich nie mogtaby bardziej rzucać się w oczy ${ }^{2}$.

W minionym dziesięcioleciu, w którym ludzkość wkroczyła w dwudziesty pierwszy wiek, muzułmanki i muzułmanie byli już żywiołowo zaangażowani w dyskusje, działania i procesy składające się na walkę o większą sprawiedliwość w islamie i myśli muzułmańskiej. Wyrażenie „większa sprawiedliwość” zakłada przekonanie, że celem islamu, historycznego ruchu zapoczątkowanego ponad czternaście wieków temu, było ustanowienie i utrzymywanie sprawiedliwego porządku społecznego. W różnych momentach jego dziejów udawało mu się realizować ten cel w wielu aspektach. Ale ponosił także porażki. Te sukcesy i porażki pokazują nam, że ani sprawiedliwość, ani islam nie są statyczne.

1 Tekst oryginalny: A. Wadud, Introduction, [w:] tejże, Inside the Gender Jihad: Women's Reform in Islam, Oxford 2006, s. 1-10 - przyp. tłum..

2 Tejże, Preface, [w:] tejże, Qur'an and Woman: Rereading the Sacred Text from a Woman's Perspective, New York 1999, s. xi. 
Muzułmańska tradycja sprawiedliwości konsekwentnie odwołuje się do dwóch z góry ustalonych źródeł: Koranu, czyli Boskiego objawienia, i sunny, wyznaczających normy zachowań Proroka Mahometa, który to objawienie otrzymał. Źródła te stanowią podstawę do trwającej nieprzerwanie dyskusji, interpretacji, reinterpretacji, kontestacji i praktyki. Ich trwałość jako punktów odniesienia sprawia, że nawet one nie mogą pozostać statyczne. Aby skutecznie rozwijać konkurencyjne koncepcje, jakie powstawały w związku ze sprawiedliwością w tym skomplikowanym okresie ludzkich dziejów, konieczne jest także ustawiczne i gruntowne badanie, jak te koncepcje i ich realizacje rozumieli ci, którzy poważnie zajmują się muzułmańską tradycją intelektualną. Powinno ono przebiegać w sposób zharmonizowany z postępującym procesem interpretacji obu wymienionych źródeł, nowoczesnym dyskursem światowym i ruchami cywilizacyjnymi. Sprawiedliwość genderowa to tylko jeden, jakkolwiek ważny, aspekt tego badania. Niektórzy twierdzą, że sama koncepcja sprawiedliwości genderowej, myślana i realizowana jako kluczowa dla społeczeństwa, wraz z poszczególnymi praktykami nieróżnicowania ze względu na płeć i promowania równości płci [gender mainstreaming], jak również zasadnicze uwzględnienie płci jako kategorii myślowej, to idee zachodnie, przeciwstawne wobec pewnych idei i praktyk zajmujących centralne miejsce w całej historii islamu. Inni spiesznie uznali, że sprawiedliwość płciowa nie jest możliwa w islamie, ponieważ feminizm, jako powstały na Zachodzie, do niego nie przystaje. Inna liczna grupa uważa, że wszelkie strategie i metody reform powinny pochodzić spoza ram religijnych. Jednak wielu myślących muzułmanów podjęło trud uwzględnienia w większym stopniu problematyki genderowej i wykazania, że istnieje zbieżność między muzułmańskimi koncepcjami sprawiedliwości a zmianami zachodzącymi ostatnio na świecie w kwestii potencjału kobiet jako pełnowartościowych ludzi. W niniejszej książce zamierzam między innymi w pewnej mierze wykazać, jak wykorzystując egalitarne tendencje, zasady oraz eksplicytne i implicytne treści obecne w islamie, przekształcić go w dynamiczny system wyposażony w praktyki urzeczywistniające jego cel: sprawiedliwość. Należy przy tym pamiętać, że sposoby rozumienia islamu, jak i sposoby rozumienia sprawiedliwości zawsze zależały od danej sytuacji historycznej i kulturowej. To, że obecnie tworzymy wspólnotę globalną, wymaga bardziej rygorystycznych badań i analiz podstawowych źródeł naszej tradycji, a w drugiej kolejności - krytycznej analizy ruchów reformistycznych zgodnych z istotą islamu, również - lub zwłaszcza - wtedy, kiedy istota ta wydaje się jaskrawo różna od niektórych jej najnowszych przejawów historycznych. Mówiąc krótko, islam, 
który istnieje tylko wtedy, gdy jest przeżywany przez ludzi, musi być przeżywany przez tych ludzi dziś. A ludzie ci nie są już odizolowani od pluralistycznego chaosu, skutków nowoczesności i następstw kolonializmu.

Moje życiowe doświadczenia jako wierzącej muzułmanki i profesorki islamistyki są ściśle związane z reformami islamu. Uczestnicząc w nich, walczę o to, by spoić w jedno dyskurs intelektualny, działalność strategiczną i holistyczną duchowość. Nie przeszłam na islam z oczyma zamkniętymi na - nadal istniejące - struktury niesprawiedliwości ani związane z nimi osobiste doświadczenia ludzi. Jednak w moim „osobistym przejściu”’ , które najczęściej nazywa się nawróceniem, z nadzieją i idealizmem skupiłam się na poszukiwaniu lepszego dostępu do Allaha pojmowanego jako „Al-Wadud”, Miłujący Bóg Sprawiedliwości. Na rzecz potwierdzania tej nadziei pracowałam przez wiele lat i na wiele sposobów. Jednak o ile doświadczenia potwierdzające ją stanowią główną motywację tej książki, to wiele aspektów świata muzułmańskiego wydaje się nieustannie oddalać od ideałów, z których czerpię natchnienie, w związku z czym muszę poważnie rozważyć działania, które należy podjąć, by odzyskać nadzieję. W mojej książce zajmuję się obszarami - centralnymi i marginalnymi - wspólnymi mnie i muzułmankom, które mimo że zaznały niezmiernego bólu i upokorzenia w imię islamu, mają nadzieję na sensowne życie i walczą o nie. Sama bezpośrednio doświadczałam rozpaczy i udręki, radości i wesela z bycia muzułmanką. Niniejsza praca powstawała w moim środowisku w Stanach Zjednoczonych, na Bliskim Wschodzie, w Afryce Północnej i Południowej, w Europie Wschodniej

3 Dr Aminah McCloud, profesorka i założycielka Islamic World Studies Program (2005) na Uniwersytecie DePaul, bardzo przekonująco argumentuje przeciw nadużywaniu słowa „nawrócenie” [conversion]. Sugeruje ono całkowite porzucenie przez daną osobę przeszłości osobistej lub zerwanie z nią i wkroczenie w coś zupełnie nowego, a tym samym jedynego w swoim rodzaju, może nawet sprzecznego z przeszłością tej osoby. W swoich badaniach McCloud jasno udowadnia, że kiedy Amerykanie-niemuzułmanie przyjmują islam - a dotyczy to i dotyczyło również innych społeczności w całym okresie rozprzestrzeniania się islamu - często czynią to jako część ciągtego procesu duchowego, moralnego i symbolicznego postępu, który zachodził już przed zaakceptowaniem przez nich szczegółowych wyznaczników islamu czy dostosowaniem się do nich. McCloud woli posługiwać się terminem "przejście” [transition], wskazując na poszczególne aspekty przeszłości człowieka jako integralne dla przejścia przezeń na islam, ale także zwracając uwagę na to, że po przejściu na islam człowiek ani nie wyklucza swojej przeszłości, ani nie staje się przez to kompletny. Będę wymiennie posługiwać się wyrażeniami „przejście” [transition] i „przekształcenie”, „przemiana” [transformation], by w ten sposób wykazać, że islam nie zaczyna się ani nie kończy na szahadzie (wyznaniu wiary). 
i Zachodniej, przede wszystkim jednak w Azji Południowo-Wschodniej. Jest to spojrzenie na zagadnienia sprawiedliwości płci w islamie z perspektywy osoby z wewnątrz.

Przeszłam na islam, mając w sercu i umyśle wiarę w to, że boską sprawiedliwość można osiągnąć na Ziemi i w całym wszechświecie. Niecałe dwa lata później przeniosłam się do Libii, arabskiego kraju w Afryce Północnej, gdzie spędziłam kolejne dwa lata. Tu zaangażowałam się w walkę o to, by tożsamość muzułmańską i praktykę islamu pojmowano w sposób bardziej egalitarny pod względem płci. Zaczęłam poszukiwać najnowszych idei i praktyk odnoszących się do marginalizowania kobiet w dziejach muzułmańskiej tradycji intelektualnej i wzmacniać, w oparciu o islam, świadomość kobiet co do rzeczywistości naszej pełnej godności ludzkiej rozumianej jako prawo boskie. Początkowo byłam zainteresowana głównie teorią, szybko jednak włączyłam się w sieci relacji łączących muzułmanki w ramach różnych organizacji muzułmańskich, zarówno męsko-kobiecych, jak i wyłącznie kobiecych. Później współpracowałam także z organizacjami rządowymi i pozarządowymi, działałam w kręgach akademickich, współpracowałam z krajowymi i międzynarodowymi niemuzułmańskimi instytucjami praw człowieka i organizacjami międzywyznaniowymi, jak również z innymi grupami zrzeszającymi kobiety. Tak się złożyło, że przyjęłam islam w czasie ważnej drugiej fali feminizmu na Zachodzie ${ }^{4}$. Muzułmanki coraz intensywniej zajmują się kwestiami istotnymi dla dobra kobiet w społeczeństwach muzułmańskich. Odsetek aktywnych uczestniczek jest dziś większy niż kiedykolwiek, choć nadal są one mniejszością na tle męskiej hegemonii i męskiego uprzywilejowania w muzułmańskim dyskursie o reformie. Większy udział kobiet w tych działaniach świadczy o zbliżaniu się do masy krytycznej, którą wytwarza zróżnicowany ruch na rzecz wzmacniania pozycji kobiet, polityki równości płci i reform z nią związanych, w tym działań uświadamiających, podwyższania poziomu edukacji, promocji i ochrony praw dziewcząt i kobiet, ruchy na rzecz ochrony kobiet i zwalczania przemocy wobec nich, ochrony cielesnej integralności kobiet, zreformowania przyjętych praktyk, zwiększania roli i repre-

4 Zachodni feminizm dzielony jest na etapy - pierwszą falę, drugą falę itd. - lecz w jego własnym łonie zgłasza się wątpliwości, czy podział taki właściwie odzwierciedla działania podejmowane przez kobiety od wielu wieków w celu podważenia męskiej hegemonii, uprzywilejowania i władzy. Posługuję się wyrażeniem „druga fala feminizmu” na Zachodzie - okres około 1960 roku - jako jednym z autoidentyfikacyjnych terminów stosowanych przez zachodnie myślicielki, działaczki i naukowczynie feministyczne. „Pierwsza fala feminizmu” - okres około 1860 roku - była po części efektem ruchu sufrażystek. 
zentacji kobiet w polityce i władzach religijnych oraz ochrony osobistej integralności duchowej.

W książce tej zawieram rozważania o islamie i sprawiedliwości społecznej w muzułmańskiej myśli i praktyce, opatrując je paroma odniesieniami do doświadczeń muzułmanek, w tym moich własnych. Przede wszystkim odnoszę się do finezyjnych i mniej finezyjnych konstrukcji płci, jakie istnieją w spektrum różnych możliwości epistemologicznych i jakich dokonuje się, formułując fundamentalne założenia islamu w zakresie ontologii. Omawiam najnowsze perspektywy i historyczne strategie w walce o równość między płciami zwłaszcza z końca dwudziestego i początku dwudziestego pierwszego wieku.

Istnieją historie, które rozpoczynają się od pojedynczego momentu. Kolejne momenty bazują na nim albo dostarczają historii uzupełniających, które nieustannie kształtują ów początek i pomagają znajdować drogi być może od niego ważniejsze. W moim wypadku początkiem trzydziestu lat zajmowania się islamem, sprawiedliwością i płcią było niesamowite światło wiary odziedziczone po ojcu, człowieku wiary i duchownym metodystycznym, który urodził się i umarł jako ubogi, czarnoskóry i uciśniony w realiach rasistowskiej Ameryki. Dorastając pod osłoną jego miłości, przewodnictwa i wiary, nigdy nie byłam uczona - i dlatego nie dostrzegałam - jakiejkolwiek sprzeczności między rzeczywistością subiektywnego doświadczenia historycznego a transcendencją wiary. To, co wewnętrzne, i to, co zewnętrzne, współistnieje i wzajemnie na siebie wpływa. Zostałam wychowana tak, by łączyć ideę boskości ze sprawiedliwością, a pojęcia sprawiedliwości - z boskością. Moja świadomość moralna zaczęła się rozwijać w momencie, gdy swoje apogeum osiągnął amerykański ruch praw obywatelskich pod przywództwem doktora Martina Luthera Kinga. Bycie córką duchownego, który tę walkę o sprawiedliwość, wyrażoną przez przywódcę religijnego, śledził z bliska i uczestniczył w niej osobiście, oczywiście wywarło na mnie swój wpływ. Dziś, kiedy gdzieś ma miejsce niesprawiedliwość, dyskryminacja i ucisk, jako muzułmanka natychmiast przypominam sobie, że Koran wyraźnie i niejednokrotnie mówi, iż Allah „nie uciska” (nie czyni zulmu) ${ }^{5}$. Zulm jest

5 Źródłosłowem [angielskiego - przyp. tłum.] wyrazu oppression [ucisk] jest łacińskie słowo oznaczające „uciskać”, „przygniatać”. Etymologia ta sugeruje, że uciskani cierpią z powodu ograniczenia ich wolności. Nie każde ograniczenie wolności człowieka jest jednak uciskiem. Ludzie nie są uciskani przez zwykłe zjawiska naturalne, na przykład siły grawitacji. „Ucisk to wynik działalności ludzkiej, ograniczenia wolności człowieka nałożonego nań przez człowieka. Jednak nie każde ograniczenie wolności człowieka nałożone przez człowieka jest uciskiem. Ucisk musi być jeszcze niesprawiedliwy" (wyróżnienie - AW): A.M. Jaggar, Femi- 
realny w kategoriach subiektywnych, historycznych, lecz jego realizacje nie mogą zgłaszać pretensji do boskiej inspiracji czy boskich wartości. Takie rozumowanie każe mi uważać się za wierzącą muzułmankę, która działa na rzecz sprawiedliwości, w oparciu o wiarę. Uważam się za muzułmankę proreligijną i profeministyczną.

Stawanie w obronie sprawiedliwości inspirowane wiarą w to, co Najwyższe, czyli boskie, zwane po arabsku „Allahem”, może wydać się sformułowaniem przesadnym. Odczuwam jednak potrzebę, by podkreślić już na początku, że nie zgadzam się z tymi, którzy odrzucają moje zapatrywania na islam i sprawiedliwość genderową, ciskając oskarżeniami o bluźnierstwo czy herezję. Czasem takie oskarżenia popychają ludzi do porzucenia perspektywy proreligijnej i przyjęcia świeckich, zachodnich sposobów artykułowania praw człowieka i sprawiedliwości społecznej. Jako muzułmanka walcząca o sprawiedliwość genderową w islamie bywałam nie tylko oskarżana o to, że działam spoza islamu i że robię, co mi się żywnie podoba, lecz także wykluczana jako antymuzułmańska. W dalszej części książki pokażę, że próby usuwania postępowych muzułmanów i muzułmanek poza ustalone z góry ramy islamu w rzeczywistości wynikają z rozstrzygnięć definicyjnych lub szczególnych interpretacji. W konsekwencji nikt, kto chce być akceptowany jako prawdziwy muzułmanin, nie może pozwolić na to, by jego walka wykroczyła poza granice powszechnie uznanego patriarchatu czy męskiej władzy, inaczej ryzykuje bowiem, że zostanie mu przyprawiona etykietka kogoś spoza islamu. Wiele szczerych kobiet i wielu szczerych mężczyzn decyduje się pozostawać w islamie takim, jaki apodyktycznie zdefiniowali muzułmańscy neokonserwatyści - specjaliści bądź laicy - czasem błędnie nazywani „fundamentalistami”, czyli po prostu decyduje się milczeć. Właśnie dlatego w naszym przedsięwzięciu najważniejsze są głosy kobiet i definicje kluczowych terminów uwzględniające kobietę. W niniejszej książce omawiam niektóre z tych terminów oraz implikacje wynikające z pragmatycznego włączenia alternatywnych definicji do wszystkich aspektów reformy islamu.

Islam nie jest monolitem. Obejmuje ogrom treści i doświadczeń. $\mathrm{Na}$ początek zajmuję się więc różnymi konstrukcjami pojęcia „islam”, nie tylko dlatego, że doświadczałam ich jako kobieta i jako muzułmanka, lecz także dlatego, że ci, którzy walczą o sprawiedliwość genderową, nieustannie zmuszani są mierzyć się z treściami będącymi przedmiotem sporów. Tak jak kilkunastu muzułmanów uzasadniających swój gwałt i przemoc w związku z zamachami z 11 września 2001 roku, które

nist Politics and Human Nature, Totowa-New Jork 1988, s. 5-6. 
w straszliwy sposób zaburzyły amerykańskie poczucie integralności i bezpieczeństwa, powoływało się na „islam”, tak też powołując się na „islam”, kobiety rodzą dzieci, ludzie odnajdują pokój i harmonię. Który obraz jest prawdziwy: oblicze zła i zniszczenia czy oblicze miłości i życia? Jak jakikolwiek pisarz, wierny czy czytelnik może pogodzić złożone i sprzeczne sensy islamu?

Zrozumiałam niedawno, że w pełni uczciwe mierzenie się z całym zakresem możliwych znaczeń i zastosowań terminu „islam” gra kluczową rolę w rozwoju mojej osobistej tożsamości jako muzułmanki, ponieważ mimo że nie identyfikuję się z zamachowcami-samobójcami ani aktami przemocy, nie mogę ignorować faktu ich istnienia w ramach szerokiej społeczności islamu. Pomimo ich obecności wśród nas przykładam dużą wagę do bycia muzułmanką. Zróżnicowane, podawane w wątpliwość i współistniejące obok siebie znaczenia „islamu” są nierozerwalnym składnikiem walk o sprawiedliwość w obecnej reformie islamu, i jest to jedna z głównych kwestii, na które zwracam uwagę w tej książce.

Bezpośrednio po moim przejściu na islam wierzyłam w ideał doskonałego islamu, będącego zarazem utopijnym pragnieniem i potencjalną rzeczywistością. To pragnienie, które historycznie pojawiało się w niektórych momentach muzułmańskiej tradycji intelektualnej, chroniło mnie przed rozdźwiękiem między utopijnym ideałem a rzeczywistością doświadczenia w świecie muzułmańskim. Rzeczywistość tę tłumaczyłam błędami w interpretacji lub niewłaściwymi praktykami powstałymi pod wpływem różnorodnych kultur, które składają się na świat islamu. Równie łatwo liberalni muzułmanie mogą odrzucać terrorystów muzułmańskich, twierdząc, że ich islam nie jest „prawdziwy”. Stosując takie uproszczenia i redukcje, nieumyślnie dawałam do zrozumienia, że właściwie to ja jedna dysponuję prawem artykułowania i posiadania na własność „prawdziwego" islamu. To aroganckie przekonanie pozwalało mi uchylać się od konieczności konfrontacji ze złem dokonywanym w imię islamu. Ważna przemiana w tej tendencji do redukcjonizmu wynikła z pewnego bolesnego doświadczenia, które stało się moim udziałem podczas II Międzynarodowej Konferencji Przywódców Muzułmańskich poświęconej HIV/AIDS (Second International Muslim Leaders Consultation on H.I.V./A.I.D.S.) ${ }^{6}$. Część muzułmańskiego audytorium gwałtownie odrzuciła moje koncepcje i poglądy, które przedstawiłam, chcąc pomóc w realizacji starań o zapewnienie sprawiedliwości najbardziej narażonym na tę szerzącą się pandemię, czyli kobietom i dzieciom.

6 Odbyła się ona w Kuala Lumpur w Malezji w maju 2003 roku. Dokładniejsza relacja z tego wydarzenia zawarta jest w rozdziale 7.

Zrozumiałam niedawno,

że w pełni uczciwe mierzenie się z całym zakresem możliwych znaczeń i zastosowań terminu „islam” gra kluczową rolę w rozwoju mojej osobistej tożsamości jako

muzułmanki, ponieważ mimo że nie identyfikuję się z zamachowcamisamobójcami ani aktami przemocy, nie mogę ignorować faktu ich istnienia w ramach szerokiej społeczności islamu 
Ci, którzy nie zgadzali się z moim stanowiskiem, rzucili mi swój sprzeciw hałaśliwie prosto w twarz, orzekli, że w świetle ich interpretacji islamu część moich uwag to bluźnierstwa, i na koniec nazwali mnie „diabłem w hidżabie”. W tamtym momencie taka impertynencja ze strony współmuzułmanów zdumiała mnie. Owo zdarzenie popchnęło mnie jednak ku nowej, choć mało komfortowej refleksji: ani ich „islam”, ani mój „islam” nie ma absolutnego pierwszeństwa. Wszyscy jesteśmy cząstkami złożonej całości, która znajduje się w nieustannym ruchu i manifestuje się w dziejach poprzez różnorodne, lecz całkowicie ludzkie konstrukcje „islamu”. W następnym rozdziale szczegółowo omówię niektóre z tych konstrukcji i przedstawię zawarte w muzułmańskich ramach uzasadnienie walki muzułmanów o egalitarny, humanistyczny, pluralistyczny islam na przyszłość.

Co ciekawe, porzucenie przekonania, że istnieje doskonałość zwana „islamem”, wolna od następstw ludzkich interakcji, pozwoliło mi porzucić moje pełne samoudręki oczekiwanie, że pewnego dnia stanę się doskonałą muzułmanką. Książka ta jest również owocem ostatnich przemian w moim życiu - życiu muzułmanki, myślicielki, działaczki i kobiety pozwalających mi zaakceptować moje wady bez konieczności poświęcania marzeń i dążeń. Na jej kartach spisany jest bój, który przez całe swoje życie toczę ze swą tożsamością muzułmanki pragnącej odzwierciedlać piękno rozległego władztwa Allaha w całej jego cudowności i chwale. Jednocześnie tożsamość ta przyznaje w wielu względach, że mnie i pozostałym muzułmanom nie udało się stworzyć wierzącej wspólnoty, która odzwierciedlałaby to piękno, nie dając nieustannie dowodów swych braków i słabości. Tak więc islam nie jest już celem - jest procesem. W proces ten trzeba się nieustannie angażować, jak czynię to od ponad trzydziestu lat, włączając w to zmaganie się z problemem relacji między znaczeniami a doświadczeniem.

Zawarte tu szkice mają różne formy, tak, by odzwierciedlać różne sposoby mojego zaangażowania w ten proces. Jedne są bardziej idealistyczne, inne - bardziej skomplikowane, abstrakcyjne i analityczne, jeszcze inne wykazują wyraźne podobieństwo do historii walk innych pisarzy, myślicieli i działaczy - zwłaszcza kobiet - działających w islamie, zarówno żywych, jak i już nieżyjących. Inne z kolei sytuują się wyraźnie na obrzeżach myśli i formy, co jest wynikiem ostatnich dyskusji, przemian, odkryć i rozczarowań. Łącząc te strukturalne niespójności będące

7 Pełną relację o tym, jak zdecydowałam się nosić to nakrycie głowy, nie uznając go w wymiarze religijnym za zasadę islamu, pomimo jego głębokiej symboliki i przemian, jakich doświadczyłam, nosząc je, zawarłam w rozdziale 7. 
elementami całości mojego doświadczenia w walce o sprawiedliwość genderową, mam nadzieję przedstawić swoje zaangażowanie się w proces poszukiwania pełni głosu i wzbogacania znaczeń bycia muzułmanką i kobietą. Całokształt tego doświadczenia i pełnia głosu wyrastają z moich skromnych przemian i obejmują zrozumienie wielorakich znaczeń słowa „islam”. W rozdziale pierwszym poddaję te wielorakie znaczenia eksplicytnej analizie, jak również przedstawiam takie znaczenia podstawowych terminów używanych w tej książce, które uwzględniają kobietę.

Uczestnicząc w tym procesie, trzymam się zwłaszcza nakazu mówiącego, że muzułmanki powinny rewindykować podstawowe źródła muzułmańskie, przede wszystkim Koran. Aby pozycja kobiet uległa wzmocnieniu, powinny one - ilekroć biorą udział w tworzeniu i reformowaniu polityki muzułmańskiej, zwłaszcza w kontekście toczących się dyskusji nad szariatem (prawem muzułmańskim) ${ }^{8}$ - wykorzystywać swoje doświadczenia do interpretowania źródeł. Interpretacje w większym stopniu uwzględniające kobiety zwiększają prawomocność ich roszczeń do władzy w ramach tradycji intelektualnej, mają także wpływ na praktyczną realizację tej tradycji. Choć moje badania skupiają się głównie na reinterpretowaniu Koranu, to użytą w nich metodologię reinterpretacyjną można na zasadzie prostej analogii stosować także do innych przedmiotów analizy, zwłaszcza szariatu - i czasami będę tak postępować. Należy tu podkreślić niedostatek badań reinterpretujących pochodzące od Proroka hadisy (przekazy ustne) i badań nad sunną, zachęcam więc innych do zwrócenia na to większej uwagi, w celu wypracowania odpowiednich podejść nieróżnicujących ze względu na płeć.

Kiedyś wydawało mi się, że moim celem w tej walce jest zaznawanie dobra w publicznej i prywatnej sferze ludzkiej egzystencji. Obcując ze zdarzeniami - intelektualnymi i praktycznymi - zachodzącymi w dziejach islamu, otoczona zmianami i wyzwaniami, doszłam do przekonania, że zaznawanie dobra jest duchową konsekwencją procesu i partycypacji. Nie jest celem. Kiedy staje się celem, często ulega zatracie9. Koran nie obiecuje nam łatwego życia, daje za to wskazówki, jak wieść życie polegające na walce i poddaniu się, ażeby osiągnąć pokój i piękno tu, na ziemi, i zbliżyć się do Najwyższego.

W jednym z dalszych rozdziałów uznaję i częściowo potwierdzam zarzuty, które kilku postępowych myślicieli płci męskiej wysunęło ostatnio wobec metodologii interpretacyjnych stosowanych przez feministki

8 Szczegółowo zajmuję się tym w rozdziale 1.

9 Wniosek ten zawdzięczam szczególnie książce S. Welch, A Feminist Ethic of Risk, Minneapolis 1990.

Aby pozycja kobiet uległa wzmocnieniu, powinny one - ilekroć biorą udział w tworzeniu i reformowaniu polityki muzułmańskiej, zwłaszcza w kontekście toczących się dyskusji nad szariatem (prawem muzułmańskim) wykorzystywać swoje doświadczenia do interpretowania źródeł 
muzułmańskie ${ }^{10}$. Niniejsza książka pokazuje jednak, że metody te nadal stanowią ważną część starań o zapewnienie legitymacji i skuteczności działań ponad pięćdziesięciu procentom ludności muzułmańskiej, które akurat są kobietami. W naszych walkach kobiety nadal są marginalizowane lub wykluczane z tego powodu, że muzułmanie mężczyźni, w tym wielu uważających się za postępowych, obejmują władzę i utrzymują ją nie tylko w oparciu o swoją własną interpretację źródeł, lecz także dlatego, że w paradygmacie muzułmańskim koncepcja domeny publicznej ciagle skupia się na stałym centrum przestrzeni publicznej, które określane i zajmowane jest głównie przez mężczyzn. Na początki współczesnych ruchów muzułmanek na rzecz wzmacniania ich pozycji i równości wielki wpływ wywarły zachodnie teorie praw kobiet i sprawiedliwości społecznej ${ }^{11}$. Taki globalny związek istnieje, niniejsza książka wskazuje jednak na liczne rozdźwięki między źródłami zachodnimi a potrzebą rodzimej, muzułmańskiej odbudowy - teoretycznej i praktycznej - w ramach dyskusji o prawach człowieka, w większej mierze odpowiadającej naszym muzułmańskim źródłom teoretycznym.

Korzyści płynące z tej prozachodniej bazy przestały mieć znaczenie wobec gwałtownego, przyspieszonego nawrotu patriarchalnie zorientowanych interpretacji źródeł, którym towarzyszyły apodyktyczne wypaczenia i losowa wybiórczość ${ }^{12}$. Muzułmanki i muzułmanie zaczęli rewindykować podstawowe teksty źródłowe, uzasadniając na ich podstawie swoje idee i cele w zamiarze wypracowania rodzimych reform islamu. Po rewindykację tekstów jako zasadniczą strategię wzmacniania swej pozycji kobiety sięgnęły jednak jako ostatnie. W końcu jednak zaczęłyśmy odnosić się wprost do podstawowych źródeł i zażądałyśmy większego równouprawnienia interpretacyjnego - i jest to nie tylko akt równości przeciwstawiający się długiej historii niemal wyłącznie męskiej władzy

10 Przeciwstawienie kilku uczonych płci męskiej metodologii „muzułmańsko-feministycznych" wyraźne jest w artykule E. Moosy, The Debts and Burdens of Critical Islam, [w:] Progressive Muslims: On Justice, Gender and Pluralism, red. O. Safi, Oxford 2003, s. 111-127.

11 Jeśli to, co obecnie uważa się za ruch muzułmańsko-feministyczny, dokładnie porównamy z wcześniejszymi artykulacjami praw muzułmanek, działaniami na rzecz tych praw i walkami, jakie w przeszłości toczyły one przeciw patriarchalnemu odbieraniu głosu i marginalizacji, zauważymy, jak bardzo złożone były to walki i że w ostatnim czasie jako fundamentalna podstawa walki o pełne człowieczeństwo kobiet dominuje teoria muzułmańska. Zob. prace autorek: Margot Badran, Deniz Kandiyoti, Azza Karam, Afsenah Najmabadi, Ziba Mir-Hosseini, Azizah al-Hibri i innych.

12 K.A. El Fadl, Speaking in God's Name: Islamic Law, Authority and Women, Oxford 2001. 
nad tekstami, lecz także droga do lepszego zrozumienia tych źródeł, pozwalająca wzmocnić zarówno naszą tożsamość w ramach islamu, jak i muzułmańską autentyczność naszych apeli o reformy.

Jeśli chodzi o wymiar bardziej osobisty, o mojej tożsamości osobistej w kontekście rozwijania myśli muzułmańskiej wiodącej do walki o sprawiedliwość genderową mówi następujący cytat:

Każdemu z nas wolno dążyć do świętego celu w taki sposób, dzięki któremu nasze życie nabierze sensu, a my będziemy dostatecznie wytrwali i konsekwentni, by z tego dążenia nie zrezygnować w ciężkich czasach ${ }^{13}$.

Dotarłam do islamu przez przypadek. Na pierwszym i drugim roku studiów zaczęłam zmieniać styl życia. Zaczęłam nosić wyłącznie długie ubrania. Włosy, już od jakiegoś czasu naturalne i niefryzowane, ścięłam krótko, a w końcu zaczęłam je zakrywać (najczęściej stosując style i zawoje afrykańskie). Zwróciłam większą uwagę na dietę, eliminując z niej mięso i wprowadzając do niej więcej zdrowej żywności. Dokonałam tych zmian ku czci własnego istnienia. Życie to dar, który należy przeżyć godnie - a nie według standardów, które na chybił trafił narzuca nam chcące wyzyskać nas otoczenie.

Pewnego razu udałam się do meczetu położonego niedaleko domu mojej matki w jednej z dzielnic Waszyngtonu. Tamtejsi bracia najwyraźniej wywnioskowali z mojego skromnego stroju, że w pełni „znam się” na islamie. Zależało im na zwiększeniu liczby kobiet wśród wiernych. Nie tłumaczyli mi wiele, powiedzieli tylko, że jeśli wierzę, iż nie ma innego bóstwa poza Allahem i Mahomet jest jego Prorokiem, to powinnam wypowiedzieć szahadę - świadectwo, czyli wyznanie wiary i pierwszy filar islamu.

Wypowiedziałam szahadę w Święto Dziękczynienia w 1972 roku. Kilka miesięcy po przyjęciu islamu zdarzył się inny wypadek, który okazał się ważny: pewna niemuzułmanka z mojej dawnej dzielnicy, położonej niedaleko meczetu, w którym wypowiedziałam szahadę, podarowała mi egzemplarz Koranu (wręczony jej przez miejscowych muzułmanów szukających konwertytek). Lektura Koranu pozwoliła mi ponownie, jak w dzieciństwie, doświadczyć istnienia światów rozmaitych znaczeń poprzez słowa. Niekiedy najprostsze sformułowania budziły we mnie wzruszenie i nabożną cześć, czasem zaś jego zawiłości zaspokajały

13 A. Wadud, On Belonging as a Muslim Woman, [w:] My Soul is a Witness: African-American Women's Spirituality, red. G. Wade-Gayles, Boston 1995, s. $253-265$. 
moje pragnienie głębszego zrozumienia. Z Koranu - któremu poświęciłam całą swą energię zawodową do czasu doktoratu, ucząc się, jak go interpretować - wyniosłam poczucie, że mogę w nim znaleźć wyjaśnienie wszystkich pytań, jakie stawiam. Nie dosłowną „odpowiedź”, jak twierdzą niektórzy, sugerując, że Koran zawiera (jedyna) Prawdę albo że znajduje się w nim cała Prawda. Koran ustanawia raczej pewną prawdziwą wizję świata i zaświatów, obejmującą znaczenia i możliwości naszej osoby, które prowadzą do pewności i pokoju.

To, że przyjęłam islam w całej pełni, zawdzięczam Koranowi, choć w swojej książce wyjawię też inne powody, dla których ściśle przestrzegam metody interpretowania w sposób uwzględniający kobiety, zwłaszcza gdy chodzi o reformy polityki publicznej. W rozdziale 6. zatytułowanym „Koran, gender i możliwości interpretacyjne” powracam do zagadnień tekstu i interpretacji uwzględniającej kobiety i przedstawiam próbę odpowiedzi na ostatnie wypowiedzi uprzywilejowanych reformistów płci męskiej, nadal roszczących sobie prawo do oceniania równouprawnienia kobiet i uzasadniania wystarczalności czy odpowiedniości ich roli $\mathrm{w}$ reformie sprawiedliwości.

Koran był dla mnie inspiracją do uczestniczenia w nieprzerwanym procesie całkowitej przebudowy w ramach muzułmańskiej spuścizny intelektualnej. Był zwłaszcza moim głównym źródłem natchnienia do przekształcania historycznych praktyk asymetrii płci. Dzięki temu natchnieniu potwierdzone zostało moje przekonanie, że sprawiedliwość genderowa jest konieczna w boskim porządku wszechświata. Odkąd skończył się kolonializm, muzułmanie i niemuzułmanie, kobiety i mężczyźni swoją świadomość niesprawiedliwości płciowej łączą z licznymi staraniami o poprawę pozycji kobiet. Starania te składają się na to, co można by nazwać „dżihadem genderowym” ${ }^{14}$. Celowo pomijam tu pejoratywne znaczenia czasami kojarzone ze słowem „dżihad” zarówno przez muzułmańskich ekstremistów, jak i zachodnich konserwatystów. „Dżihad” dotyczy „trudu”, „wysiłku” 15 i w tym miejscu tłumaczony będzie jako „walka”. Dżihad genderowy to walka o ustanowienie sprawiedli-

14 Dziękuję Na’eem Jeenah za pomoc w dotarciu do pierwszego użycia tego wyrażenia u Rashieda Omara, który posługiwał się nim wraz z wyrażeniem „dżihad ekonomiczny”, mówiąc o koncepcjach wymagających zrewidowania w rzeczywistości postapartheidowej. Odesłała mnie także do pracy F. Esacka, Qur'an Liberation and Pluralism: an Islamic Perspective of Interreligious Solidarity Against Oppresion, Oxford 1997, s. 239-248.

15 Jednym z podstawowych źródeł informacji na ten temat jest cykliczny program Worlds of Faith z Billem Moyersem i Hustonem Smithem. Szeroka dyskusja wokół dżihadu toczy się od wydarzeń 11 września 2001 roku. 
wości genderowej w muzułmańskiej myśli i praktyce. Na poziomie najbardziej podstawowym sprawiedliwość genderowa to gender mainstreaming - włączanie kobiet we wszystkie aspekty muzułmańskiej praktyki, we władze polityczne i religijne, konstruowanie muzułmańskich programów politycznych i społecznych. Niniejsza książka skupia się na walce o sprawiedliwość genderową, lecz zarazem ma wzbogacić korpus literatury stawiającej sobie za cel wyrugowanie wszelkich publicznych i prywatnych praktyk gwałcących w imię islamu pełne człowieczeństwo kobiet. Podobne wykluczające i dehumanizujące praktyki wymierzone są w niemuzułmanów i, coraz częściej, w nieheteroseksualnych muzułmanów.

Jako muzułmanka żyjąca i współpracująca z muzułmankami z całego świata spotkałam ich dostatecznie dużo, by wiedzieć, jak wiele z nich stara się odnaleźć swoją tożsamość i pełnię głosu, tocząc nieustanną walkę w ramach dżihadu genderowego - w sposób zamierzony bądź przypadkowy. Niniejsza książka włącza się u zarania dwudziestego pierwszego wieku w chór donośnych głosów tworzących pieśni - i uczących się ich - o tym, czym jest ,islam” w pełni obejmujący prawdziwie istniejące muzułmanki. Posłuchajcie naszej pieśni, a gdy jej słowa zabrzmią znajomo, zaśpiewajcie z nami, gdyż naszą pieśnią nazbyt często było milczenie, które podtrzymywało i zasilało drugi plan. Dziś musimy zrozumieć, że estetyczna równowaga i harmonia mogą powstać jedynie $\mathrm{z}$ równego zespolenia tego drugiego planu z pierwszym, cieszącym się uznaniem lokalnym, krajowym, międzynarodowym i światowym.

Przetożyt Marcin Michalski 
AMINA WADUD (1952) - amerykańska badaczka islamu, w latach 1992-2008 związana z Virginia Commonwealth University. Autorka Qur'an and Woman: Rereading the Sacred Text from a Woman's Perspective (1999) oraz Inside the Gender Jihad: Women's Reform in Islam (2006).

\section{Cytowanie:}

A. Wadud, Genderowy dżihad reforma w islamie, „Praktyka Teoretyczna” nr 2(8)/2013, http://www.praktykateoretyczna.pl/PT_nr8_2013_Teologie_emancypacyjne/11.Wadud.pdf (dostęp dzień miesiąc rok)

Słowa kluczowe: islamski feminizm, sprawiedliwość genderowa, koran, kolonializm 